\title{
CONTRIBUIÇõES DE UMA SEQUÊNCIA DIDÁTICA PARA A PROMOÇÃO DA ÁLFABETIZAÇÃO CIENTÍFICA NOS ANOS INICIAIS
}

\section{CONTRIBUTIONS OF A TEACHING SEQUENCE FOR THE PROMOTION OF SCIENTIFIC LITERACY IN THE EARLY YEARS}

Lucimara Fabrício ${ }^{1}$

ORCID iD: $\underline{0000-0001-5347-3993}$

Leonir Lorenzetti ${ }^{2}$

ORCID iD: $\underline{0000-0001-8327-9147}$

Alisson Antonio Martins ${ }^{3}$

ORCID iD: $\underline{0000-0002-4431-2247}$

\begin{abstract}
RESUMO
Esta pesquisa objetivou analisar as possíveis contribuições de uma sequência didática para a promoção da alfabetização científica junto aos alunos de uma turma de $5^{\circ}$ ano que frequentam uma escola municipal de educação integral e jornada ampliada no município de Curitiba (PR). O método de pesquisa foi de natureza qualitativa, conduzido por intervenção pedagógica. A sequência didática foi planejada com base nos eixos estruturantes de alfabetização científica. A constituição dos dados se deu por meio de diálogos e produção de atividades experimentais desenvolvidas na oficina de Práticas de Ciência e Tecnologia e teve como temática as células. A análise dos dados ocorreu por meio da utilização de três categorias de alfabetização científica, denominadas: funcional, conceitual e processual, e multidimensional. Os resultados mostraram evidências de maior expressão das categorias funcional e a conceitual e processual em relação a multidimensional, ou seja, os alunos conseguiram mobilizar, progressivamente, os conceitos científicos apreendidos para a resolução das atividades experimentais propostas e puderam se posicionar de forma fundamentada frente às discussões promovidas. Concluímos que o uso de sequências didáticas planejadas, a partir dos referenciais propostos, pode potencializar a oportunidade de aprendizagem dos estudantes e incentivar a aplicação dos conhecimentos científicos adquiridos no seu cotidiano.
\end{abstract}

Palavras-chave: Alfabetização Científica. Ciências. Sequência Didática. Anos Iniciais. Célula.

\footnotetext{
${ }^{1}$ Mestre em Educação Científica, Educacional e Tecnológica pela Universidade Tecnológica Federal do Paraná (UTFPR). Professora da Educação Básica na Prefeitura Municipal de Curitiba, Paraná, Brasil. Endereço para correspondência: Rua Capitão Lopes Quintas,198, Alto Boqueirão, Curitiba, Paraná, Brasil, CEP: 81860-090. Email: lucimara_fabricio@yahoo.com.br.

${ }^{2}$ Doutor em Educação Científica e Tecnológica pela Universidade Federal de Santa Catarina (UFSC). Professor do Departamento de Química e do Programa de Pós-Graduação em Educação em Ciências e em Matemática da Universidade Federal do Paraná (UFPR). Atua também no Programa de Formação Científica, Educacional e Tecnológica da Universidade Tecnológica Federal do Paraná (UTFPR), Curitiba, Paraná, Brasil. Endereço para correspondência: Av. Cel. Francisco H. dos Santos, 100 - Jardim das Américas, Curitiba, Paraná, Brasil, CEP: 81530-000. E-mail: leonirlorenzetti22@gmail.com.

${ }^{3}$ Doutor em Educação pela Universidade Federal do Paraná (UFPR). Professor do Departamento Acadêmico de Física e do Programa de Pós-Graduação em Formação Científica, Educacional e Tecnológica da Universidade Tecnológica Federal do Paraná (UTFPR). Atua também no Programa de Pós-Graduação em Educação da Universidade Federal do Paraná (UFPR), Curitiba, Paraná, Brasil. Endereço para correspondência: Av. Sete de Setembro, 3165 - Rebouças, Curitiba, Paraná, Brasil, CEP: 80230-901. E-mail: amartins@utfpr.edu.br.
} 


\begin{abstract}
This research aimed to analyze the contributions of a didactic sequence for the promotion of scientific literacy to students of a 5th grade class of elementary school in a county school of integral education and extended hours in the city of Curitiba (PR). The research method was qualitative, conducted by pedagogical intervention. The didactic sequence was planned based on the structuring axes of scientific literacy. The constitution of the data took place through dialogues and production of experimental activities developed in the Science and Technology Practices workshop and had cells as the theme. The data analysis occurred through the use of three categories of scientific literacy, named: functional, conceptual and procedural, and multidimensional. The results showed evidence of greater expression of the functional and the conceptual and procedural categories in relation to the multidimensional, that is, the students were able to progressively mobilize the scientific concepts learned for the resolution of the proposed experimental activities and were able to position themselves in a reasoned way before the promoted discussions. We conclude that the use of planned didactic sequences, based on the proposed references, can enhance the students' learning opportunity and encourage the application of scientific knowledge acquired in their daily lives.
\end{abstract}

Keywords: Scientific Literacy. Sciences. Didactic Sequence. Elementary School. Cell.

\title{
1 INTRODUÇÃO
}

Muito tem se discutido sobre uma necessária renovação do ensino de Ciências em todos os níveis da Educação Básica. A preocupação tem sido objeto de pesquisa em grande parte dos países e apresenta críticas aos problemas enfrentados no cotidiano escolar. Esses problemas atingem grande porcentagem de alunos e alunas que, muitas vezes, não participam de um ambiente escolar que incentive debates e discussões contextualizados e relacionados em torno de temas sociocientíficos e sociotecnológicos. Esses pressupostos estão em sintonia com autores como Lorenzetti (2001), Cachapuz et al. (2011), Delizoicov, Angotti e Pernambuco (2011), Gil-Pérez e Vilches-Peña (2001), Berto e Lorenzetti (2019) e Santos et al. (2006), entre outros, que discutem e apresentam a alfabetização científica (AC) como uma possibilidade para o desenvolvimento da cidadania no contexto da Educação Básica. Essa proposta de ensino e aprendizagem dentro da linguagem das Ciências Naturais visa a apropriação significativa dos conhecimentos científicos e a ampliação do universo de conhecimentos dos alunos. A perspectiva parte da necessidade de uma compreensão crítica do mundo, que possibilite o discernimento e as escolhas conscientes, com vistas a uma melhor qualidade de vida. Entendese que esse processo educativo, aqui denominado $\mathrm{AC}$, é uma construção que se prolonga por toda a vida. Contudo, ressalta-se que é importante empregar a abordagem desde a fase inicial da escolarização, conforme apontado por Lorenzetti e Delizoicov (2001) e Viecheneski e Carletto (2013). 
Nutrindo-se dessas referências, o presente estudo teve por objetivo analisar as possíveis contribuições de uma sequência didática (SD) para a promoção da Alfabetização Científica. O local da pesquisa foi a Escola Municipal CEI Maestro Bento Mossurunga, em uma região periférica do município de Curitiba (PR). A SD teve sua temática relacionada a células e foi aplicada em uma turma de 30 alunos do $5^{\circ}$ ano do Ensino Fundamental 1, nas aulas de Práticas de Ciência e Tecnologia ${ }^{4}$, no período do contraturno em regime de educação integral de jornada ampliada.

O artigo discorre sobre a proposta, implementação e análise de uma SD elaborada com vistas a aproximar o conhecimento científico com os saberes comuns da realidade dos alunos. Para se refletir sobre o que significa promover a $\mathrm{AC}$ para os estudantes dos anos iniciais, procurou-se convergir a construção das atividades desenvolvidas com as ideias apresentadas por Sasseron e Carvalho (2008) sobre os eixos estruturantes da AC e analisar suas potencialidades de promoção de conhecimento utilizando os parâmetros indicadores apresentados por Bybee (1995).

\section{OS EIXOS ESTRUTURANTES E OS PARÂMETROS DE ALFABETIZAÇÃO CIENTÍFICA}

Os eixos estruturantes da AC, propostos por Sasseron e Carvalho (2008), consistem em três pontos que servem de apoio na idealização, planejamento e análise das propostas de ensino. (1) O primeiro eixo refere-se à compreensão básica de termos, conhecimentos e conceitos científicos fundamentais. Ele é importante para que os alunos possam relacionar conceitos com informações e atividades do dia-a-dia. (2) O segundo eixo trata da compreensão da natureza da ciência, assim como dos fatores éticos e políticos que circundam a sua prática. Esse eixo exige reflexões de como as investigações científicas são realizadas e das análises cuidadosas frente às circunstâncias de nosso cotidiano que envolvam a ciência. (3) O terceiro eixo é relativo às relações CTS (Ciência, Tecnologia e Sociedade) e como esses fatores se relacionam e afetam a nossa vida.

Um dos grandes anseios relativos à perspectiva da AC é tentar identificar "níveis" de progressão do estudante. Para isso, autores como Shen (1975), Fourez (1994), Bybee (1995) e

\footnotetext{
${ }^{4}$ As escolas municipais integrais de tempo ampliado de Curitiba são aquelas em que o aluno realiza 4 horas em aulas regulares e 4 horas em período de contraturno escolar. Nesse contraturno são realizados projetos em oficinas em diversas práticas de ensino, sendo uma delas as Práticas de Ciência e Tecnologia.
} 
Bocheco (2011) desenvolveram pesquisas sobre parâmetros que indicam níveis de apropriação da AC. Para este estudo, optou-se pelo trabalho de Bybee (1995), por estar relacionado aos níveis de apropriação da AC, mais especificamente, no contexto escolar. Segundo o autor, existem três dimensões graduais da $\mathrm{AC}$ : a funcional, a conceitual e processual e a multidimensional.

$\mathrm{Na} \mathrm{AC}$ funcional a ênfase está na aquisição e no desenvolvimento de conceitos e vocabulários apropriados para a ciência e a tecnologia, ou seja, de acordo com a idade dos educandos, fase de desenvolvimento, e o nível de educação, os estudantes deveriam estar aptos a ler e escrever passagens que incluem vocabulário científico e tecnológico.

$\mathrm{Na} \mathrm{AC}$ conceitual e processual os alunos atribuem significados próprios aos conceitos científicos. Aqui o entendimento não se restringe ao vocabulário e ao uso dos conceitos específicos da área, mas trata da apropriação desses conceitos pelos estudantes. Nessa dimensão, os alunos desenvolvem as habilidades e compreensões relativas aos procedimentos científicos, não os dicotomizando em conceitos e produtos.

[...] nós temos de ajudar os estudantes a desenvolver perspectivas de ciência e tecnologia que incluam a história das ideias científicas, a natureza da ciência e da tecnologia, e o papel da ciência e da tecnologia na vida pessoal e na sociedade (BYBEE, 1995, p. 29).

Já a AC multifuncional ocorre quando os indivíduos são capazes de adquirir e explicar conhecimentos além de aplicá-los na solução de problemas do dia-a-dia.

Uma das críticas que Bybee (1995) destaca em seu trabalho, é a demasiada ênfase que os docentes de Ciências têm dado para a AC funcional em relação as outras categorias. Priorizam muito o aspecto quantitativo da aprendizagem, isto é, dando valor ao número de conceitos aprendidos e ao vocabulário científico, em detrimento do aspecto qualitativo, isto é, da contextualização desses conceitos e a real atribuição de significados a eles.

\section{METODOLOGIA}

O presente estudo caracteriza-se como uma pesquisa qualitativa, de intervenção pedagógica. Esse tipo de pesquisa apresenta as seguintes características:

1) são pesquisas aplicadas, em contraposição a pesquisas fundamentais;

2) partem de uma intenção de mudança ou inovação, constituindo-se, então, em práticas a serem analisadas; 
3) trabalham com dados criados, em contraposição a dados já existentes, que são simplesmente coletados;

4) envolvem uma avaliação rigorosa e sistemática dos efeitos de tais práticas, isto é, uma avaliação apoiada em métodos científicos, em contraposição às simples descrições dos efeitos de práticas que visam a mudança ou inovação (DAMIANI et al., 2013, p. 7).

Para esses autores, as pesquisas de intervenção pedagógica são "investigações que envolvem o planejamento e a implementação de interferências (mudanças, inovações) destinadas a produzir avanços, melhorias, nos processos de aprendizagem dos sujeitos que delas participam - e a posterior avaliação dos efeitos dessas interferências" (DAMIANI, et al., 2013, p. 58).

Nesse sentido o trabalho apresenta uma proposta de intervenção pedagógica, materializada por meio de uma sequência didática elaborada de acordo com os eixos estruturantes de AC propostos por Sasseron e Carvalho (2008).

Essa sequência teve como temática as células. A relevância do conteúdo está primeiramente em fazer parte do currículo municipal do $5^{\circ}$ ano, e depois na possibilidade que oferece de despertar interesse nos alunos para a compreensão dos fenômenos científicos.

O trabalho pedagógico foi desenvolvido em 16 horas/aula, que aconteceram ao longo de aproximadamente 2 meses. As atividades da SD ocorreram de acordo com o esquema apresentado na Figura 1.

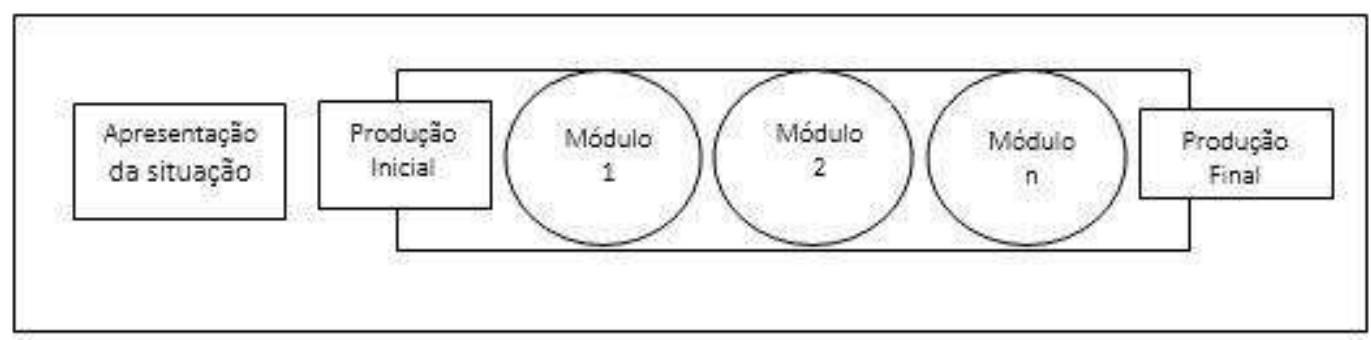

Figura 1 - Esquema da sequência didática.

Fonte: Dolz, Noverraz e Schneuwly (2004, p. 98).

A realização das atividades dentro dessas etapas se deu conforme descrito a seguir. (1) O conteúdo a ser trabalhado foi apresentado aos estudantes de forma dialógica, bem como as etapas da SD. (2) Na produção inicial, foi realizada uma avaliação diagnóstica na qual os alunos apresentaram oralmente seus conhecimentos prévios relacionados ao conteúdo. A utilização de perguntas, como elementos disparadores, foi uma estratégia utilizada para conduzir o diálogo. (3) Os módulos representam as atividades desenvolvidas durante as aulas. Nos módulos foram trabalhados os conteúdos e as questões levantadas na avaliação diagnóstica. (4) Na produção final, foi realizado o desenvolvimento prático dos módulos (Quadro 1) e avaliado o 
desenvolvimento dos alunos por meio de suas participações e avanços demonstrados durante as

aulas. Para essa avaliação, houve montagem de portfólios com as atividades realizadas, utilizando: fotografias, registros de atividades, ilustrações e observações.

\begin{tabular}{|c|c|c|c|}
\hline Fase & Objetivos & Disparadores & $\begin{array}{l}\text { Recursos didáticos e Materiais } \\
\text { utilizados }\end{array}$ \\
\hline $\begin{array}{l}\text { 1: Célula } \\
\text { (Visão geral) }\end{array}$ & $\begin{array}{l}\text { Reconhecer a célula } \\
\text { como unidade básica } \\
\text { que constitui os seres } \\
\text { vivos, identificando } \\
\text { organismos unicelulares } \\
\text { e pluricelulares. }\end{array}$ & $\begin{array}{l}\text { Você conhece seu } \\
\text { corpo, como ele é por } \\
\text { dentro? Todos os seres } \\
\text { vivos são iguais? O que } \\
\text { temos em comum? } \\
\text { Você sabe o que é a } \\
\text { uma célula? }\end{array}$ & $\begin{array}{l}\text { - Texto: "O que é unicelular e } \\
\text { pluricelular" do site Universidade } \\
\text { das Crianças. } \\
\text { - Imagens impressas de células. } \\
\text { - Construção de maquetes de célula } \\
\text { unicelular com materiais recicláveis. }\end{array}$ \\
\hline $\begin{array}{l}\text { 2: Célula } \\
\text { Procariótica }\end{array}$ & $\begin{array}{l}\text { - Reconhecer a célula } \\
\text { como unidade básica } \\
\text { que constitui os seres } \\
\text { vivos, identificando } \\
\text { organismos unicelulares } \\
\text { e pluricelulares. } \\
\text { - Discutir a relação das } \\
\text { bactérias com os } \\
\text { avanços tecnológicos. }\end{array}$ & $\begin{array}{l}\text { Quem são os seres } \\
\text { vivos unicelulares? } \\
\text { Todas as células } \\
\text { unicelulares têm o } \\
\text { mesmo formato? }\end{array}$ & $\begin{array}{l}\text { - Vídeo: "Bactérias: o que são? Onde } \\
\text { vivem? O que fazem? } \\
\text { - Construção de célula procariótica } \\
\text { com biscoito tipo maisena. } \\
\text { - Construção de maquetes com } \\
\text { massinha de modelar. } \\
\text { - Pesquisa no laboratório de } \\
\text { informática. } \\
\text { - Carteira de vacinação. } \\
\text { - Rótulos de iogurte. } \\
\text { - Experimento: produção de iogurte. }\end{array}$ \\
\hline $\begin{array}{l}\text { 3: Célula } \\
\text { Eucariótica }\end{array}$ & $\begin{array}{l}\text { Reconhecer a célula } \\
\text { como unidade básica } \\
\text { que constitui os seres } \\
\text { vivos, identificando } \\
\text { organismos unicelulares } \\
\text { e pluricelulares. }\end{array}$ & $\begin{array}{l}\text { Células humanas são } \\
\text { iguais às das bactérias? }\end{array}$ & $\begin{array}{l}\text { - Microscópio e lâmina pronta de } \\
\text { uma célula eucariótica. } \\
\text { - Imagens impressas de célula } \\
\text { eucariótica tirada em microscópio } \\
\text { óptico e eletrônico. } \\
\text { - Construção de maquete de célula } \\
\text { eucariótica. } \\
\text { - Reportagem: "Família lança } \\
\text { campanha para ajudar bebê com } \\
\text { doença genética rara". }\end{array}$ \\
\hline $\begin{array}{l}\text { 4: Célula } \\
\text { Vegetal }\end{array}$ & $\begin{array}{l}\text { Diferenciar célula } \\
\text { animal da célula vegetal. }\end{array}$ & $\begin{array}{l}\text { Células de animais são } \\
\text { iguais de células } \\
\text { vegetais? }\end{array}$ & $\begin{array}{l}\text { - Construção de maquetes de células } \\
\text { vegetais. } \\
\text { - Receita de suco verde. } \\
\text { - Experimento: extração de } \\
\text { pigmentos. }\end{array}$ \\
\hline $\begin{array}{l}\text { 5: Tipos de } \\
\text { células no } \\
\text { nosso corpo. }\end{array}$ & $\begin{array}{l}\text { Reconhecer } r \text { os } \\
\text { diferentes tipos de célula } \\
\text { que compõe o nosso } \\
\text { corpo. }\end{array}$ & $\begin{array}{l}\text { As células de um ser } \\
\text { vivo são todas iguais? }\end{array}$ & $\begin{array}{l}\text { - Vídeo: "A evolução do } \\
\text { microscópio e das células". } \\
\text { - Microscópio e lâminas prontas de } \\
\text { diferentes células do corpo. } \\
\text { - Desenhos das lâminas observadas. }\end{array}$ \\
\hline $\begin{array}{l}\text { 6: DNA e } \\
\text { testes de } \\
\text { paternidade }\end{array}$ & $\begin{array}{l}\text { - Reconhecer que todos } \\
\text { os organismos, } \\
\text { apresentam em suas } \\
\text { células o material } \\
\text { genético: DNA. } \\
\text { - Identificar técnicas } \\
\text { relacionadas aos testes } \\
\text { de paternidade. }\end{array}$ & $\begin{array}{l}\text { O que é um teste de } \\
\text { paternidade? Qual a } \\
\text { relação com as nossas } \\
\text { aulas? }\end{array}$ & $\begin{array}{l}\text { - Vídeo "Como são feitos os testes } \\
\text { de paternidade". } \\
\text { - Experimento: extração de DNA do } \\
\text { morango. }\end{array}$ \\
\hline
\end{tabular}




\begin{tabular}{|l|l|l|l|}
\hline $\begin{array}{l}\text { 7: Tópicos } \\
\text { de genética - } \\
\text { diversidade }\end{array}$ & $\begin{array}{l}\text { - Reconhecer que todos } \\
\text { os organismos, } \\
\text { apresentam em suas } \\
\text { células o material } \\
\text { genético. } \\
\text {-Relacionar o material } \\
\text { genético com o fenótipo. }\end{array}$ & $\begin{array}{l}\text { Por que somos } \\
\text { diferentes? }\end{array}$ & $\begin{array}{l}\text { - Livro "Por que somos de cores } \\
\text { diferentes?" De Carmem Gil. } \\
\text { - Construção de bonecos de palito. }\end{array}$ \\
\hline $\begin{array}{l}\text { 8: Jogo "A } \\
\text { diversidade" }\end{array}$ & $\begin{array}{l}\text { Relacionar o material } \\
\text { genético com o fenótipo. }\end{array}$ & $\begin{array}{l}\text { O que é genética? Para } \\
\text { que serve? }\end{array}$ & $\begin{array}{l}\text { - Livro: "Os cientistas e seus } \\
\text { experimentos de arromba" de Mike } \\
\text { Goldsmith. } \\
\text { - Vídeo "Mendel e a ervilha" } \\
\text { - Jogo "A diversidade". }\end{array}$ \\
\hline
\end{tabular}

Quadro 1- Relação dos conteúdos e recursos didáticos utilizados em cada fase. Fonte: dados da pesquisa.

Apresentamos a seguir alguns exemplos de atividades que foram trabalhadas em cada módulo e sua descrição a fim de reconhecer suas potencialidades.

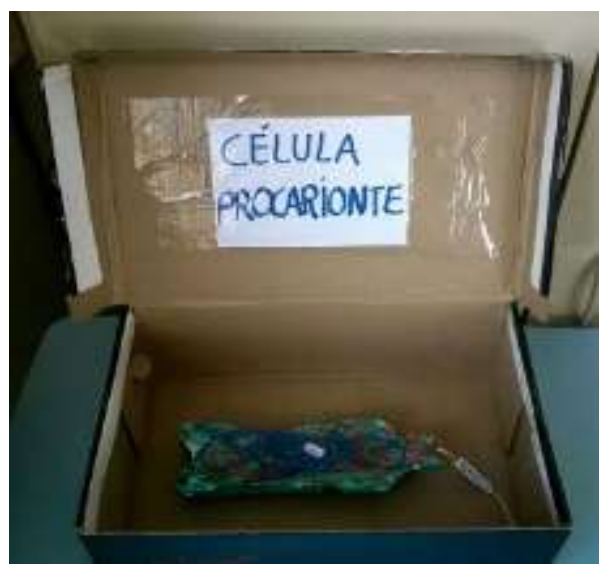

Figura 2 - Maquete de célula procariótica. Fonte: dados da pesquisa.

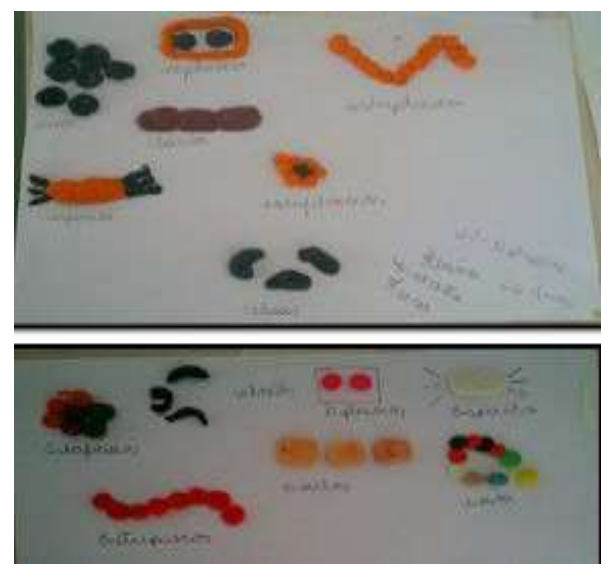

Figura 3 - Maquete de bactérias. Fonte: dados da pesquisa.

A fase 1 da sequência didática tinha como foco apresentar uma visão geral da célula. Foram apresentadas aos alunos, de forma genérica, ideias gerais sobre a célula, sua importância e seus tipos: procarionte e eucarionte. Nesse módulo focou-se nas células procariontes, como mostra a Figura 2.

Na fase 2 (Célula Procariótica), os alunos realizaram diferentes atividades. Conheceram os diferentes conceitos e vocábulos envolvendo as partes da célula procariótica e suas funções, relacionando esses seres com sua importância ecológica, com as doenças e com a utilidade no dia-a-dia, conforme consta na Figura 3. 


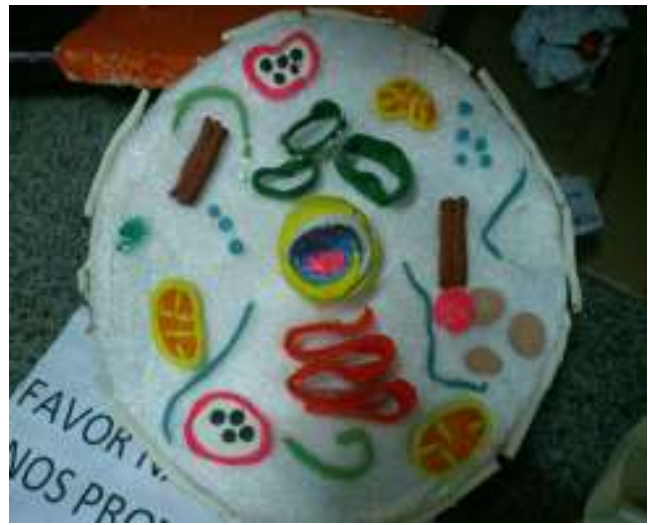

Figura 4 - Maquete de célula animal. Fonte: dados da pesquisa.

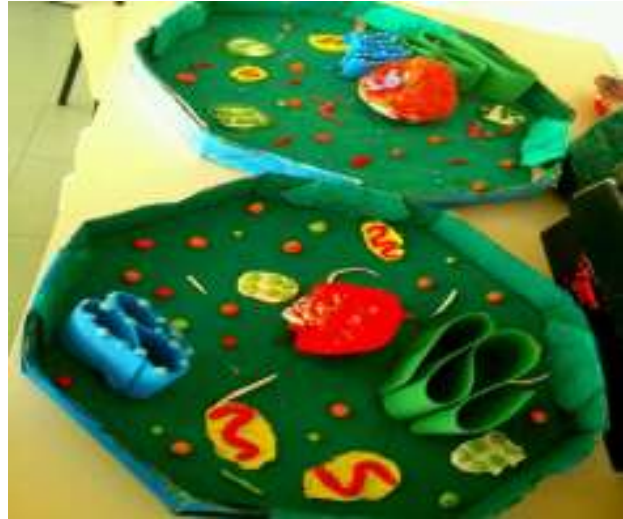

Figura 5 - Maquete de célula vegetal. Fonte: dados da pesquisa.

$\mathrm{Na}$ fase 3 (Célula Eucariótica), respeitando a faixa etária dos alunos e de seu desenvolvimento, os alunos apreenderam que a célula é mais complexa do que somente membrana, citoplasma e núcleo, como geralmente é apresentado nos livros didáticos (Figura 4). Com auxílio de pesquisas, leituras e reflexões de reportagens, eles puderam relacionar doenças às atividades das organelas.

Na fase 4 (Célula Vegetal), foi possível verificar as diferenças entre células vegetais e animais, relacionando as suas diferenças com o que podemos visualizar nas plantas, como por exemplo, os pigmentos (Figura 5).

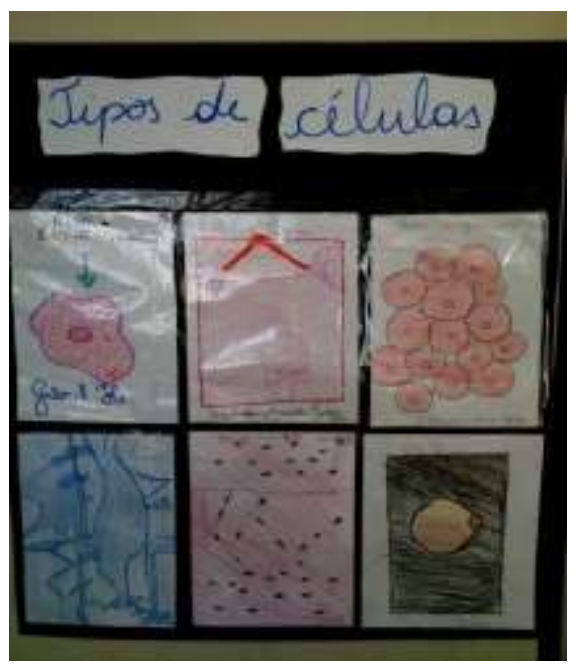

Figura 6 - Desenho de diferentes células humanas. Fonte: dados da pesquisa.

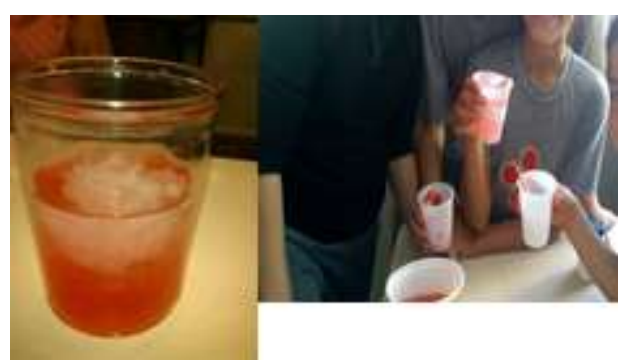

Figura 7 - Extração de DNA. Fonte: dados da pesquisa.

Na fase 5 (Tipos de células no nosso corpo), com o auxílio do microscópio e de lâminas, foi possível visualizar diferentes tipos de células no nosso organismo e foi discutido o porquê de não podermos visualizar as organelas (FIGURA 6). Nessa prática, os alunos puderam 
conhecer um pouco a história da ciência, especialmente sobre o desenvolvimento e uso dos microscópios e lentes, as contribuições dos cientistas, e foi possível discutir, de forma genérica, como se dá a produção de novos conhecimentos.

Na fase 6 (DNA e testes de paternidade), os alunos aprenderam o que é DNA e fizeram leitura de reportagens sobre teste de paternidade e realizaram discussões e experimentos sobre esse assunto (FIGURA 7).

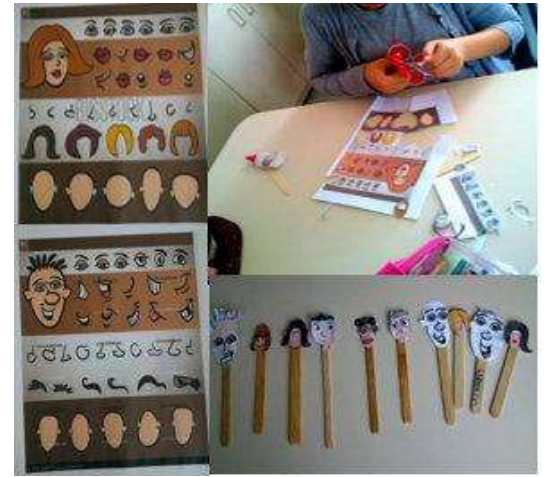

Figura 8 - Bonecos de palitos. Fonte: dados da pesquisa.

A fase 7 (Tópicos de genética - diversidade) envolveu a montagem de bonecos de palitos de sorvete (FIGURA 8) com o recorte de diferentes características do nosso corpo. Os alunos puderam, desse modo, perceber a diversidade genética expressa nos seres humanos, assim como nas outras espécies.

$\mathrm{Na}$ fase 8 (Jogo "A diversidade"), os alunos participaram de um jogo intitulado "A diversidade". Através de conceitos e vocabulários científicos apropriados, puderam relacionálos e internalizá-los de forma significativa e lúdica (FIGURA 9). Nesse jogo, após a apropriação dos conceitos científicos relacionados à Genética, tais como dominante e recessivo, a professora dava os comandos e os alunos deveriam criar um ser vivo de acordo com as características mencionadas (FIGURA 10). Exemplo da figura: sexo XY (macho), antena AA (vermelha), pintas nas asas pp (ausente), cauda CC (alongada) e Dedos Dd (presente). 


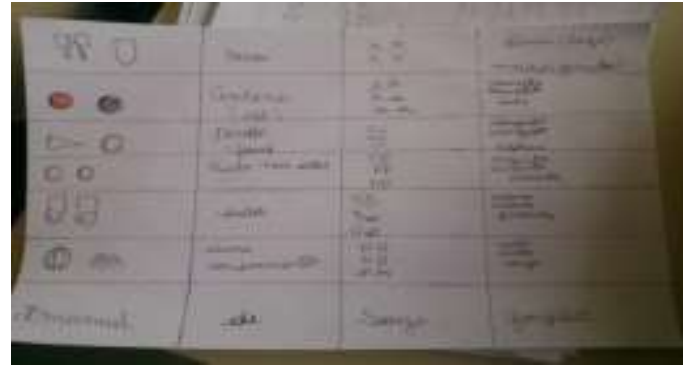

Figura 9 - Jogo "A diversidade". Fonte: dados da pesquisa.

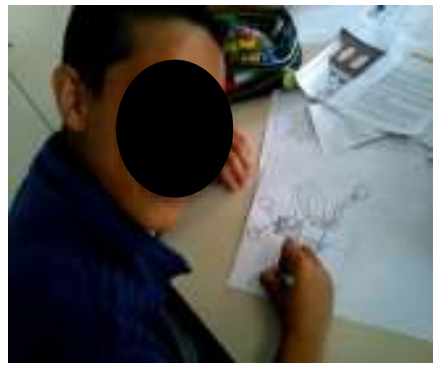

Figura 10 - Jogo "A diversidade". Fonte: dados da pesquisa.

A análise dos dados ocorreu por meio da análise de textual discursiva (MORAES; GALIAZZI, 2011), sendo que os parâmetros indicadores de AC propostas por Bybee (1995) foram considerados como categorias a priori.

\section{ANÁLISES E RESULTADOS}

Ao longo das aulas, percebeu-se, que os alunos apresentaram conhecimentos prévios muito limitados do tema proposto, restringindo-se de um modo geral a um famoso programa de TV, que tem um quadro titulado "Testes de DNA", mas faltavam conhecimentos sobre células. Como podemos perceber no Quadro 2, no decorrer das atividades foi verificado nitidamente um progressivo avanço sobre esses temas.

\begin{tabular}{|l|c|c|c|}
\hline Fase & AC funcional & AC conceitual e processual & AC multifuncional \\
\hline Fase 1 & + & + & \\
\hline Fase 2 & + & + & + \\
\hline Fase 3 & + & + & \\
\hline Fase 4 & + & + & + \\
\hline Fase 5 & + & + & + \\
\hline Fase 6 & + & + & + \\
\hline Fase 7 & + & + & \\
\hline Fase 8 & + & +1 & \\
\hline
\end{tabular}

Quadro 2 - Potencial de AC em cada uma das fases desenvolvidos na sequência didática. Fonte: dados da pesquisa.

A seguir, são discutidos os resultados dentro de cada uma das categorias. 


\subsection{Alfabetização Científica Funcional:}

No decorrer das atividades propostas, os alunos foram saindo do senso comum conforme adquiriam conceitos científicos e vocábulos apropriados a Ciência e Tecnologia, como, por exemplo, conceitos de DNA, célula, genética; vocábulos como testes de paternidade, doenças bacterianas, diversidade, os nomes científicos, entre outros, como apresentado no Quadro 3.

\begin{tabular}{|c|c|}
\hline Fase & Exemplo de ocorrência de AC funcional \\
\hline Fase 1 & Conceito de célula. \\
\hline Fase 2 & Utilizar nomes científicos das bactérias. Ex: Lactobacilos. \\
\hline Fase 3 & Nomear as partes da célula. \\
\hline Fase 4 & Conceito de clorofila. \\
\hline Fase 5 & Discutir a história da ciência, pela contribuição de alguns cientistas. \\
\hline Fase 6 & Experiência da extração do DNA: conceituar DNA. \\
\hline Fase 7 & Diversidade genética e a relação com o DNA: conceituar diversidade genética e fenótipo. \\
\hline Fase 8 & Elementos da genética: alelos dominante x recessivo. \\
\hline
\end{tabular}

Quadro 3 - Exemplo de elementos que caracterizam a ocorrência de A.C Funcional. Fonte: dados da pesquisa.

A categoria Alfabetização Científica Funcional esteve expressa em todas as fases. Essas atividades ocorreram respeitando a idade, a fase de desenvolvimento e o nível de educação dos educandos. Essa aquisição ocorreu de forma gradativa, no decorrer do desenvolvimento dos módulos. Os alunos perceberam que no Ensino de Ciências há palavras específicas, termos e linguagens próprias e em todas as atividades percebeu-se um ganho no número de apropriações desses conceitos e vocábulos. Porém, esse ganho quantitativo de conceitos e vocábulos não é suficiente para a promoção da AC. Aliás, a restrição ao ganho de conceitos e vocábulos caracteriza uma abordagem tradicionalista da educação, que não é o foco deste trabalho. Porém, o acesso a esses conhecimentos é fundamental para que ocorra a ascensão a outros níveis de AC.

Como apontado por Sasseron e Carvalho (2008) é importante a compreensão básica de termos, conhecimentos e conceitos científicos fundamentais, pois são determinantes para compreender e responder a pequenas informações do dia-a-dia. 


\subsection{Alfabetização Científica Conceitual e Processual}

Nesse nível espera-se que os educandos desenvolvam competências, ou seja, que consigam mobilizar os conhecimentos adquiridos, principalmente por meio de conceitos e vocábulos, para relacioná-los com as informações e fatos sobre a Ciência e Tecnologia no seu dia-a-dia. Espera-se que os estudantes possam relatar informações e experiências que unifiquem os campos da Ciência.

Na construção das atividades que visavam atender a essas expetativas, buscamos trazer atividades relacionadas à construção histórica da ciência e às investigações científicas frente às circunstâncias de nosso cotidiano. Quanto à contextualização dos temas da SD com o cotidiano dos alunos, os alunos identificaram como os significados e conceitos apreendidos se expressam na natureza (Quadro 4).

\begin{tabular}{|c|c|}
\hline FDSD & Exemplo de atividade com ocorrência de AC conceitual e processual \\
\hline Fase 2 & Relacionar a produção do iogurte com a bactéria (Lactobacilo). \\
\hline Fase 3 & $\begin{array}{c}\text { Leitura de reportagens relacionando doenças genéticas a "falhas" no funcionamento da } \\
\text { célula. }\end{array}$ \\
\hline Fase 4 & Relacionar o suco verde com o pigmento das plantas. \\
\hline Fase 5 & História da Ciência: a descoberta do microscópio. \\
\hline Fase 6 & Como é feito os testes de paternidade. \\
\hline Fase 7 & Diversidade genética na natureza. \\
\hline Fase 8 & Diversidade genética na natureza. \\
\hline
\end{tabular}

Quadro 4 - Exemplo de atividades com ocorrência de AC conceitual e processual. Fonte: dados da pesquisa.

$\mathrm{Na}$ fase 2, por exemplo, ao estudar as células procariontes, por meio de atividades como, a construção de maquetes, pesquisas na internet, leitura de rótulos e o experimento da produção do iogurte, os estudantes associaram as bactérias dos tipos Lactobacillus e Streptococcus com a função delas na fermentação e textura do iogurte. O mesmo ocorreu para o reconhecimento de suas estruturas com algumas doenças descritas na carteira de vacinação, como o tétano, que é uma doença causada pelo bacilo tetânico, a meningite, causada por uma bactéria tipo coccobacilar, entre outras. O reconhecimento da importância da vacinação foi outro fator muito importante dentro dessa categoria.

$\mathrm{Na}$ fase 3, os estudantes confrontaram o funcionamento das células com doenças. A leitura e a reflexão sobre reportagens introduziram os alunos no contexto do conteúdo que está 
sendo trabalhado. Foi uma atividade limitada, porém atendeu à expectativa de relacionar o estudo de células com doenças que ocorrem devido a falhas genéticas, ou seja, o reconhecimento que a célula é mais complexa do que geralmente aparece nos livros didáticos dos anos iniciais. Outro fator importante foi o reconhecimento de que o mecanismo celular é passível de falhas, e, no caso da leitura da reportagem pesquisada, a falha associava-se à genética dos pais. Aqui e em outras fases ficou claro que as atividades de leitura e materiais que não fossem somente os livros didáticos, como jornais, revistas, músicas, poemas e livros paradidáticos, são importantes instrumentos e estratégias didáticas que auxiliam o professor na mediação dialógica com seus alunos, para que melhor compreendam os assuntos expostos.

$\mathrm{Na}$ fase 4 foi possível explorar o porquê de o suco verde ser dessa cor, a partir da identificação de que as células vegetais são diferentes das células animais. No experimento da extração de pigmentos, foi visualizado o reconhecimento da existência de outros pigmentos nas plantas, além da clorofila, bem como suas funções. Já na fase 5, ao examinar no microscópio os diferentes tipos de células do nosso corpo, os alunos estudaram como são feitas as lentes desses equipamentos, sobre a sua história, que abordou desde as primeiras lentes de Galileu até as de Robert Hooke. Essa atividade visou o reconhecimento de que a ciência é uma construção histórica, que depende de fatores como, por exemplo, muitas pesquisas, lançamento de hipóteses, do papel da curiosidade e da criatividade.

As fases 6, 7 e 8, tiveram como objetivo conectar a temática da célula, especificamente a genética, com a expressão de seu conteúdo na natureza, seu fenótipo, como por exemplo, os testes de paternidade que são apresentados diariamente no famoso programa de TV. Destacamos que a ludicidade foi um fator importante para compreender alguns conceitos e tópicos básicos da genética. Essa ludicidade foi crucial diante de um assunto que, nos anos finais e ensino médio, é considerado de difícil compreensão pelos estudantes.

\subsection{Alfabetização Científica Multifuncional}

Para que ocorra a AC multifuncional, os estudantes devem demonstrar capacidade de adquirir e explicar conhecimentos, relacionando-os ao seu dia-a-dia, e de discernir que a ciência é um processo de natureza antropológica, ou seja, é uma construção humana. Na AC multifuncional os estudantes devem entender as perspectivas da Ciência e da Tecnologia que incluem ideias sobre a história da Natureza da Ciência, suas regras na vida pessoal e na sociedade (Quadro 5). 


\begin{tabular}{|c|c|}
\hline Fase & Exemplos de atividades com ocorrência de AC multifuncional \\
\hline Fase 2 & Produção de iogurte pelas bactérias (suas regras e métodos). A importância da \\
& vacinação. \\
\hline Fase 6 & $\begin{array}{r}\text { Uso de metodologia apropriada para a extração do DNA de morangos e relacionar o } \\
\text { DNA extraído com testes de paternidade. }\end{array}$ \\
\hline Fase 8 & $\begin{array}{c}\text { No desenvolvimento do jogo "A diversidade” os alunos relacionaram conceitos e } \\
\text { tópicos de genética. }\end{array}$ \\
\hline
\end{tabular}

Quadro 5 - Exemplo de atividade com ocorrência de AC multifuncional. Fonte: dados da pesquisa.

O Quadro 5 aponta resultados relativos à importância da ciência na vida das pessoas seja ela de ordem econômica, cívica ou tecnológica, bem como a dependência desses fatores entre si. Nas Fases 2, 6 e 8 os alunos compreenderam, mesmo que de forma não aprofundada, visto que são alunos do ensino fundamental 1, que os conhecimentos científicos influenciam a economia, a saúde e a dependência por tecnologia.

Essa categoria expressou um desafio, tanto na elaboração da SD, no reconhecimento das relações CTS, quanto na avaliação dos alunos, pois os estudos nessa área demandam o conhecimento multi e interdisciplinar. Avaliar a expressão de um juízo de valores, principalmente éticos, baseado nesse conjunto de atividades, também representou uma outra dificuldade, principalmente, dada a importância para a formação do pensamento crítico.

\section{CONSIDERAÇÕES}

Nesse trabalho nos propusemos analisar as contribuições de uma sequência didática sobre células para a promoção da Alfabetização Científica. Ela apresentou alguns resultados positivos dentro de todas as categorias para sinais de promoção da alfabetização científica. Dado a esse cenário, podemos realizar algumas inferências.

A primeiro ponto está relacionado com as vivências dentro de escolas integrais de tempo ampliado. Essa ampliação, num contexto de contraturno escolar, aqui representada na Prática Pedagógica de Ciência e Tecnologia, possibilitou aos alunos acesso a estratégias de ensino e tempo de estudo diferenciado do que geralmente o ensino regular oferece. Os trabalhos em projetos dentro de uma metodologia ativa representam uma constante dialogicidade e cooperação entre os alunos, num cenário de constante investigação, uso da criatividade, respeito a seus pares, entre outros. 
A segunda consideração diz respeito à experiência ter possibilitado reconhecer a importância da promoção da alfabetização científica já nos primeiros anos do ensino fundamental. Demonstrou também que sequências didáticas estruturadas dentro dos referenciais propostos podem oportunizar para os estudantes tanto aprendizado, quanto interação na cultura científica e aplicação dos conhecimentos adquiridos no seu cotidiano.

Outro aspecto diz respeito à necessidade de revisão e ampliação do que foi apresentado aqui. Os resultados demonstram que foram atingidas as três categorias, porém não em todas as fases da sequência didática. Pensando, principalmente, na categoria multifuncional, levantamos o questionamento de como trabalhar os conceitos científicos de forma que, já nos anos iniciais, a historicidade da ciência seja considerada, que a ciência deixe de ser vista como elemento neutro e linear, um ensino que fuja dos estereótipos e respeite a natureza da ciência. Outro fator pertinente, refere-se à avaliação. A coletânea de materiais, composta no portfólio por fotografias, registros, entre outros, se mostrou insuficiente. Assim, sugere-se o uso de gravações dos diálogos, o uso da análise discursiva, para melhor compreender o fenômeno estudado, além do uso de mapas conceituais, como proposto por Silva e Lorenzetti (2018).

Concluímos finalmente que, apesar de não atingir completamente todos os propósitos, esse artigo apresenta possíveis caminhos para reflexões de práticas pedagógicas, que assumam um caráter de pedagogia libertadora e que possa tirar os sujeitos do senso comum para dentro do conhecimento científico, filosófico e artístico.

\section{REFERÊNCIAS}

BERTO, José Alexandre; LORENZETTI, Leonir. Sequência didática para estudo da queda dos corpos: uma possibilidade de educação científica. Revista REAMEC-Rede Amazônica de Educação em Ciências e Matemática, Cuiabá, v. 7, n.2, p. 261-279, 2019. Disponível: https://periodicoscientificos.ufmt.br/ojs/index.php/reamec/article/view/8632/pdf. Acesso em 10.set.2020.

BOCHECO, Otávio. Parâmetros para a abordagem de evento no enfoque CTS. 2011. 165 f. Dissertação (Mestrado em Educação Científica e Tecnológica) - Centro de Ciências da Educação, Universidade Federal de Santa Catarina, Florianópolis, 2011. Disponível em: https://repositorio.ufsc.br/handle/123456789/95281. Acesso em: 23.abr.2020.

BYBEE, Rodger W. “Achieving Scientific Literacy”. In: The Science Teacher, v.62, n.7, p. 28-33, Arlington: United States oct.1995.

CACHAPUZ, Antônio; GIL-PEREZ, Daniel; CARVALHO, Anna Maria Pessoa de; PRAIA, João; VILCHES, Amparo. A necessária renovação do ensino de Ciências. 3 ed. São Paulo: Cortez, 2011. 
DAMIANI, Magda Floriano; ROCHEFORT, Renato Siqueira; CASTRO, Rafael Fonseca de; DARIZ, Marion Rodriguez; PINHEIRO, Silvia Siqueira. Discutindo pesquisas do tipo intervenção pedagógica. Cadernos de Educação, Pelotas, n. 45, p. 57 - 67, jul./ago. 2013. Disponível em: https://periodicos.ufpel.edu.br/ojs2/index.php/caduc/article/view/3822. Acesso em: 22.abr.2020.

DELIZOICOV, Demétrio; ANGOTTI, José André; PERNAMBUCO, Marta Maria. Ensino de Ciências: fundamentos e métodos. 4. ed. São Paulo: Cortez, 2011.

DOLZ, Joaquim; NOVERRAZ, Michèle; SCHNEUWLY, Bernard. Gêneros orais e escritas na escola. São Paulo: Mercado de Letras, 2004.

FOUREZ, Gerard. Alphabétisation Scientifique et Technique. Bruxelles, Belgium, 1994.

GIL-PÉREZ, Daniel; VILCHES-PEÑA, Amparo. Una alfabetización científica para el siglo XXI: obstáculos y propuestas de actuación. Investigación en la Escuela, v. 43, n.1, p. 27-47. 2001. Disponível em: https://revistascientificas.us.es/index.php/IE/article/view/7667/6782. Acesso em: 05.abr.2020.

LORENZETTI, Leonir; DELIZOICOV, Demétrio. Alfabetização científica no contexto das séries iniciais. Ensaio - Pesquisa em Educação em Ciências, Belo Horizonte, v. 3, n. 1, p. 45-61. 2001. Disponível em: https://www.scielo.br/pdf/epec/v3n1/1983-2117-epec-3-0100045. Acesso em 25.mar.2020.

MORAES, Roque; GALIAZZI, Maria do Carmo. Análise textual discursiva. 2. ed. Ijuí: Editora Unijuí, 2011.

SANTOS, Wildson Luiz Pereira dos; GAUCHE, Ricardo; MÓL, Gerson de Souza; SILVA, Roberto Ribeiro da; BAPTISTA, Joice de Aguiar. Formação de professores: uma proposta de pesquisa a partir da reflexão sobre a prática docente. Ensaio- Pesquisa em Educação em Ciências. Belo Horizonte, v.8, n.1, p. 62-89. 2006. Disponível em: https://www.scielo.br/pdf/epec/v8n1/1983-2117-epec-8-01-00069.pdf. Acesso em: 22.abr.2020.

SASSERON, Lúcia Helena; CARVALHO, Anna Maria Pessoa de. Almejando a Alfabetização Científica no Ensino Fundamental: a proposição e a procura de indicadores do processo. Investigações em Ensino de Ciências. Porto Alegre, v. 13, n.3, p. 333-352. 2008. Disponível em: https://www.if.ufrgs.br/cref/ojs/index.php/ienci/article/view/445. Acesso em: 22.abr.2020.

SHEN, Benjamin Shih Ping. Science Literacy. American Scientist, v. 63, n.3, p. 265-268. 1975 .

SILVA, Virgínia Roteurs da; LORENZETTI, Leonir. A utilização dos mapas conceituais na pesquisa em educação em ciências. REAMEC - Rede Amazônica de Educação em

Ciências e Matemática, Cuiabá, v. 6, n. 1, p. 43-64, 2018. Disponível em: https://periodicoscientificos.ufmt.br/ojs/index.php/reamec/article/view/5922. Acesso em: 11 set. 2020. 
VIECHENESKI, Juliana Pinto; CARLETTO, Márcia Regina. Sequência didática para o ensino de ciências nos anos iniciais: subsídios para iniciação à alfabetização científica.

Revista Dynamis, Blumenau, v. 19, n. 1, p. 3-16. 2013. Disponível em:

https://bu.furb.br/ojs/index.php/dynamis/article/view/3262. Acesso em: 22.abr.2020.

Submetido em: 23 de abril de 2020.

Aprovado em: 19 de julho de 2020. 